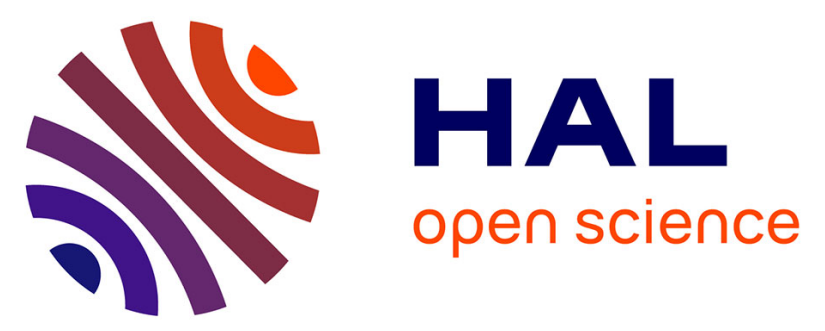

\title{
Using X-ray Computed Tomography to Describe the Dynamics of Nitrous Oxide Emissions during Soil Drying
}

Eva Rabot, Marine Lacoste, Catherine Hénault, Isabelle Cousin

\section{To cite this version:}

Eva Rabot, Marine Lacoste, Catherine Hénault, Isabelle Cousin. Using X-ray Computed Tomography to Describe the Dynamics of Nitrous Oxide Emissions during Soil Drying. Vadose Zone Journal, 2015, 14 (8), 10 p. 10.2136/vzj2014.12.0177 . insu-01241590

\section{HAL Id: insu-01241590 \\ https://hal-insu.archives-ouvertes.fr/insu-01241590}

Submitted on 10 Dec 2015

HAL is a multi-disciplinary open access archive for the deposit and dissemination of scientific research documents, whether they are published or not. The documents may come from teaching and research institutions in France or abroad, or from public or private research centers.
L'archive ouverte pluridisciplinaire HAL, est destinée au dépôt et à la diffusion de documents scientifiques de niveau recherche, publiés ou non, émanant des établissements d'enseignement et de recherche français ou étrangers, des laboratoires publics ou privés.

\section{(1) (1) $\$$}

Distributed under a Creative Commons Attribution - NonCommercial - NoDerivatives 44.0 


\section{Vadose Zone Journal}

\section{Using X-ray computed tomography to describe the dynamics of nitrous oxide emissions during soil drying}

\begin{tabular}{|r|l|}
\hline Journal: & Vadose Zone Journal \\
\hline Manuscript ID: & VZJ-2014-12-0177-ORA.R1 \\
\hline Manuscript Type: & Original Research Articles \\
\hline Date Submitted by the Author: & 10-Apr-2015 \\
\hline Complete List of Authors: & $\begin{array}{l}\text { RABOT, Eva } \\
\text { LACOSTE, Marine } \\
\text { Henault, Catherine } \\
\text { Cousin, Isabelle }\end{array}$ \\
\hline Keywords: & $\begin{array}{l}\text { soil, nitrous oxide, X-ray computed tomography, gas diffusivity, pore } \\
\text { connectivity }\end{array}$ \\
\hline
\end{tabular}

SCHOLARONE ${ }^{\text {Im }}$

Manuscripts 
1 Using X-ray computed tomography to describe the dynamics of nitrous oxide emissions

2 during soil drying

3 E. Rabot ${ }^{1,2}$, M. Lacoste $^{2}$, C. Hénault ${ }^{2}$, I. Cousin ${ }^{2, *}$

$4{ }^{1}$ Laboratoire Léon Brillouin, UMR12, CEA Saclay, 91191 Gif-sur-Yvette Cedex, France

$5 \quad 2$ INRA, UR0272, UR Science du Sol, F-45075 Orléans, France

6 * Corresponding author: isabelle.cousin@orleans.inra.fr

\section{Impact statement}

8 We proposed a methodology to image the water dynamics and the soil structure of a soil

9 sample with X-ray computed tomography, while controlling the hydric state and monitoring

$10 \mathrm{~N}_{2} \mathrm{O}$ fluxes. Relevant information about $\mathrm{N}_{2} \mathrm{O}$ transport could be extracted from the images.

\section{Abstract}

12 Water in soil is known to be a key factor for controlling nitrous oxide $\left(\mathrm{N}_{2} \mathrm{O}\right)$ emissions,

13 because $\mathrm{N}_{2} \mathrm{O}$ is mainly produced by denitrification in anoxic environments. In this study, we

14 proposed a methodology to image the water and soil structure of a soil sample with X-ray

15 computed tomography, while controlling the hydric state and monitoring $\mathrm{N}_{2} \mathrm{O}$ fluxes. We

16 used a multistep outflow system to apply two wetting-drying cycles to an undisturbed soil.

17 The soil core was scanned with coarse-resolution X-ray computed tomography, one time during wetting and several times during drying, to measure quantitative and qualitative indicators of the pore network. Nitrous oxide emissions were higher during the first $(\mathrm{C} 1)$ than during the second (C2) wetting-drying cycle, both for the wetting and the drying phases. Fluxes increased quickly after the beginning of the drying phase to reach a peak after $5 \mathrm{~h}$. Differences in the intensity of $\mathrm{N}_{2} \mathrm{O}$ emissions between the two cycles were attributed to differences in the water saturation, air-phase connectivity, and relative gas diffusion coefficient, which led to more or less $\mathrm{N}_{2} \mathrm{O}$ production, consumption, and entrapment in soil. The speed of the $\mathrm{N}_{2} \mathrm{O}$ emissions at the beginning of the drying phase depended on the rate of increase of the air-filled pore volume and connectivity, and was especially well described by the estimated relative gas diffusion coefficient. Parameters of the soil structure were not able 
Abbreviations: C1: first wetting-drying cycle; C2: second wetting-drying cycle; WFPS: water filled pore space.

\section{Introduction}

Nitrous oxide $\left(\mathrm{N}_{2} \mathrm{O}\right)$ concentration in the atmosphere is constantly increasing (Khalil et al., 2002). With a global warming potential 300 times higher than that of carbon dioxide over a 100-year time scale (World Meteorological Organization, 2007), $\mathrm{N}_{2} \mathrm{O}$ is the gas with the third largest contribution to global warming (Ciais et al., 2013). Nitrous oxide plays also an important role in the stratospheric ozone depletion (Ravishankara et al., 2009). Soils are a major source of $\mathrm{N}_{2} \mathrm{O}$, accounting for $60 \%$ of natural sources (soils under natural vegetation) and $60 \%$ of anthropogenic sources (soils used for agriculture; Ciais et al., 2013). Nitrous oxide is produced during the natural microbial reactions of nitrification and denitrification, two reactions which are controlled by the status of aerobiosis in soils. Since the water saturation of soils modifies the ratio between water-filled and air-filled pore space, the waterfilled pore space (WFPS) is often used as an indicator of $\mathrm{N}_{2} \mathrm{O}$ emissions (Butterbach-Bahl et al., 2013; Robertson, 1989). In particular, wetting and drying cycles are known to affect $\mathrm{N}_{2} \mathrm{O}$ emissions (Guo et al., 2014; Muhr et al., 2008). Peaks of $\mathrm{N}_{2} \mathrm{O}$ emissions have often been observed both in the field and in laboratory experiments after the rewetting of a soil (Groffman and Tiedje, 1988; Sanchez-Martin et al., 2010; Sexstone et al., 1985).

Following the model proposed by Smith (1980), $\mathrm{N}_{2} \mathrm{O}$ production can occur inside anoxic aggregates and then diffuse to the soil surface through inter-aggregate pores. Thus, delays between microbial production and the moment when $\mathrm{N}_{2} \mathrm{O}$ can be measured at the soil surface have been demonstrated (Clough et al., 1998; McCarty et al., 1999; Rabot et al., 2014; Weier et al., 1993; Wollersheim et al., 1987). Delays in $\mathrm{N}_{2} \mathrm{O}$ emissions are partly linked to gas entrapment and the associated dissolution of $\mathrm{N}_{2} \mathrm{O}$ in the water phase (Clough et al., 2005). We hypothesize here that introducing dynamic indicators of the soil structure could enhance our 
55

56

57

58

59

60

61

62

63

64

65

66

67

68

69

70

71

72

73

74

75

76

understanding of the dynamic nature of $\mathrm{N}_{2} \mathrm{O}$ emissions during wetting and drying cycles, by a better description of $\mathrm{N}_{2} \mathrm{O}$ transport. Indeed, since soil structure controls the water and gas dynamics in soils, and thus the aerobic microbial activity, soil structure is supposed to be of great importance for $\mathrm{N}_{2} \mathrm{O}$ emissions (Ball, 2013).

Both the soil water and soil structure can be studied by X-ray computed tomography. X-ray computed tomography is rapid, non-destructive, and allows successive scans over time while measuring other dynamic parameters, such as $\mathrm{N}_{2} \mathrm{O}$ fluxes. It provides 3-D images, used to perform spatial analysis of the soil sample. In soil science, X-ray computed tomography is a common tool, used for example to study the effect of agricultural practices (Deurer et al., 2009; Schjønning et al., 2013; Schlüter et al., 2011), the water dynamics (Kasteel et al., 2000; Sammartino et al., 2012; Wildenschild et al., 2005), or the gas dynamics (Deurer et al., 2009; Katuwal et al., 2014; Naveed et al., 2013). Katuwal et al. (2014) demonstrated the interest of coarse-resolution X-ray scanners to study gas transport functioning in macropores. This methodology can be applied to $\mathrm{N}_{2} \mathrm{O}$ emissions. Only few studies used imaging techniques to study greenhouse gas emissions (e.g., Mangalassery et al., 2014; Mangalassery et al., 2013), and to our knowledge, none of them monitored greenhouse gases while acquiring images of the soil structure.

In this study, we proposed a methodology to image the water and soil structure of a soil sample with coarse-resolution X-ray computed tomography, while controlling the hydric state and monitoring $\mathrm{N}_{2} \mathrm{O}$ fluxes. We aimed at demonstrating which relevant information can be extracted from the images to allow a better understanding of $\mathrm{N}_{2} \mathrm{O}$ emissions. We illustrated this methodology by subjecting a soil sample to two wetting and drying cycles. 


\subsection{Soil sampling, physical and chemical characterization}

The study site was chosen for the high $\mathrm{N}_{2} \mathrm{O}$ emissions previously recorded in the field (Gu et al., 2011), at the same location as the study of Rabot et al. (2014). The site is an agricultural field cultivated with rape (Brassica napus L.), located near Chartres, in the northwest of France $\left(48.376^{\circ} \mathrm{N}\right.$ lat, $1.196^{\circ} \mathrm{E}$ long). The soil is classified as Glossic Retisol (WRB, 2014), with a clay content of $13.7 \%$, a silt content of $82.0 \%$, and a sand content of $4.3 \%$ (Rabot et al., 2014). A soil core was collected in June 2013 in a PVC cylinder (13.2-cm inner diameter by 7-cm height) from the surface horizon $(1-8 \mathrm{~cm})$. Bulk soil was also sampled in the surface horizon for physical and chemical analyses. Soil organic carbon was measured by sulfochromic oxidation, and total nitrogen was measured by the Dumas method. The soil nitrate content was determined by colorimetric analysis after the extraction from an 8-g soil sample using $0.5 \mathrm{M} \mathrm{K}_{2} \mathrm{SO}_{4}$. Soil $\mathrm{pH}$ was determined in a 1:2.5 soil/water volume ratio on samples sieved at $<2 \mathrm{~mm}$. At the sampling time, the soil organic carbon was $9.5 \mathrm{~g} \mathrm{~kg}^{-1}$, the total nitrogen content was $0.91 \mathrm{~g} \mathrm{~kg}^{-1}$, the nitrate content was $51.3 \mathrm{mg} \mathrm{NO}_{3}{ }^{-}-\mathrm{N} \mathrm{kg}^{-1}$, and the soil $\mathrm{pH}$ was 5.6. The porosity of the soil sample was $0.46 \mathrm{~cm}^{3} \mathrm{~cm}^{-3}$ and the volumetric water content was $37.7 \%$ (equivalent to $81.9 \%$ WFPS). The sample was conditioned in a plastic bag and stored field moist during two weeks at $5^{\circ} \mathrm{C}$ to minimize microbial activity. Before the start of the experiment, the soil core was trimmed on each end and maintained at $20^{\circ} \mathrm{C}$ for 24 h.

\subsection{Experimental setup}

The experiment consisted in controlling the hydric status of the soil sample with a multistep outflow system (Weihermüller et al., 2009): the soil cylinder was connected to a water-tank to control its wetting according to the Mariotte bottle principle, and connected to a vacuum 
101 pump and a sampling bottle to control its drying (Fig. 1). Hydraulic continuity was ensured

102 with a porous ceramic plate (1-bar air-entry value, $8.6 \times 10^{-8} \mathrm{~m} \mathrm{~s}^{-1}$ saturated hydraulic 103 conductivity, Soilmoisture Equipment Corp.) placed at the bottom of the soil cylinder and 104 previously saturated with water. The soil cylinder-ceramic plate system was sealed with 105 silicon to avoid water or gas leaks. Both the water content and water potential were 106 continuously monitored during the experiment, with a balance $(0.1 \mathrm{~g}$ precision $)$ and two 107 microtensiometers (porous ceramic cup, 20-mm length, 2.2-mm diam., 150-kPa air-entry 108 value) inserted at 2 and $4 \mathrm{~cm}$ from the cylinder surface at the end of the wetting phase. Data 109 were recorded every 10 min with a datalogger (CR1000, Campbell Scientific).

110 Two wetting-drying cycles (hereafter referred to as the $\mathrm{C} 1$ and $\mathrm{C} 2$ cycles) were applied to the 111 soil cylinder. The initial water content for $\mathrm{C} 1$ was the water content at sampling. The sample 112 was first saturated for $3 \mathrm{~d}$ by raising the water level to the soil surface in one step, and then a $113-100 \mathrm{hPa}$ pressure was applied at the bottom of the soil core in one step, and maintained for 114 about $7 \mathrm{~h}$ (C1 cycle). A zero hPa pressure was then applied for $3 \mathrm{~d}$, followed by a $-100 \mathrm{hPa}$ 115 pressure for about $7 \mathrm{~h}$ (C2 cycle). Indeed, Rabot et al. (2014) demonstrated that $\mathrm{N}_{2} \mathrm{O}$ peaks 116 can be created during the drying phase, at a matric potential of approximately $-50 \mathrm{hPa}$. We 117 chose thus to apply a pressure lower than this value of $-50 \mathrm{hPa}$. The speed of the matric 118 potential decrease was much higher that under natural conditions, and could affect the water 119 transport and hydraulic continuity. We used a $\mathrm{KNO}_{3}$ solution as the wetting fluid, to ensure 120 that nitrate was not a limiting factor for $\mathrm{N}_{2} \mathrm{O}$ emissions during the wetting phase, and to 121 isolate the effects of nitrate concentration and soil moisture on the $\mathrm{N}_{2} \mathrm{O}$ emissions. Hénault 122 and Germon (2000) showed that the response of $\mathrm{N}_{2} \mathrm{O}$ emissions to the nitrate concentration 123 could be described by a Michaelis-Menten function. We used a nitrate concentration at the 124 plateau of this function $(4.1 \mathrm{mM} \mathrm{N})$. The nitrate solution was prepared with de-aired water to 125 prevent air bubble formation during the experiment. 
126 Nitrous oxide emissions were monitored by infrared correlation spectroscopy $\left(\mathrm{N}_{2} \mathrm{O}\right.$ Analyzer

127 model 46i, Thermo Scientific) using a 4-L volume closed-chamber. The emissions were

128 measured for 20-min periods, and the concentration value was recorded every minute. Given

129 the linear increase of the $\mathrm{N}_{2} \mathrm{O}$ concentration in the closed-chamber, $\mathrm{N}_{2} \mathrm{O}$ fluxes were

130 calculated linearly from the observed change in concentration during the first 10 min after the

131 chamber was closed. Only one $\mathrm{N}_{2} \mathrm{O}$ flux measurement was done during wetting, at the end of

132 each wetting phase for each cycle, and seven (respectively eight) flux measurements were

133 recorded during the drying phase for the $\mathrm{C} 1$ (respectively C2) cycle. Moreover, gases inside

134 the chamber were sampled in evacuated vials at the end of the wetting phase and at the middle

135 of the drying phase ( $3.5 \mathrm{~h}$ after the beginning of the drying phase), and $\mathrm{CO}_{2}$ concentration was

136 determined by gas chromatography ( $\mu \mathrm{GC}$ Gas Analyzer T-3000, SRA Instruments). For a

137 single $\mathrm{CO}_{2}$ flux measurement, the atmosphere of the closed-chamber was sampled three times

138 during 20-min periods. Given the linear increase of the $\mathrm{CO}_{2}$ concentration, the flux was then

139 calculated linearly. The chamber was removed before each measurement to restore the

140 atmosphere to ambient concentrations of gases. The sample was kept inside the scanner

141 during the two wetting-drying cycles. The temperature inside the scanner room was monitored

142 and ranged between 22.5 and $25.5^{\circ} \mathrm{C}$ throughout the experiment.

\section{$143 \quad 2.3$ Computed tomography and image analyses}

144 The soil sample was placed in the scanner in its sampling direction. The soil sample was

145 scanned one time at the end of the wetting phase, and the vacuum pump was then activated to

146 begin the soil drying. We then scanned the sample seven times for $\mathrm{C} 1$, and nine times for $\mathrm{C} 2$

147 during the drying phase, alternating with $\mathrm{N}_{2} \mathrm{O}$ flux measurements. Two scans have been added

148 at $\mathrm{C} 2$ compared to $\mathrm{C} 1$ to refine the results just after the beginning of the drying phase. We

149 used a medical X-ray tomograph (Siemens Somatom Definition AS) operating at an energy 
150 level of $200 \mathrm{kV}$ and a current of $140 \mathrm{~mA}$. The voxel size was $316 \times 316 \times 100 \mu \mathrm{m}$. The scanning

151 duration was 15 seconds. In the following, intensities are expressed in Hounsfield units (HU).

152 Most of the image processing was realized with the ImageJ software (Rasband, 1997-2014).

153 Due to the chamber manipulation during the experiment and displacement of the sample

154 between scans, image registration was first done to ensure spatial consistency between the

155 different images with the Align3 TP plugin (Parker, 2012). We cropped the images to exclude

156 non-soil areas, and we rescaled the images to get isotropic voxels of $316 \mu \mathrm{m}$. The noise was

157 reduced by using a bilateral filter, and edges were enhanced with an unsharp mask (Schlüter

158 et al., 2014). The air phase and the water phase were both separated from the soil matrix and

159 gravels by using the watershed segmentation method. This method has previously been

160 successfully used to segment images of soils (Schlüter et al., 2014). A majority filter with a

$1613 \times 3 \times 3$ kernel was applied to remove very small air-filled and water-filled pores which can be

162 seen as noise. We finally removed manually the signal of the two tensiometers. The procedure

163 used to segment the air phase and the water phase gave satisfactory results (Fig. 2).

164 Visualization of the air-filled and water-filled pore network was done with the ImageJ plugin

165 3-D Viewer (Schmid et al., 2010).

166 The volume of air-filled and water-filled macropores was estimated with the BoneJ plugin

167 (Doube et al., 2010), and the Euler number was calculated considering 26-connectivity with

168 the C library QuantIm v.4 (Vogel, 2008), on the segmented images. The Euler number

169 characterizes the connectivity of the air-filled pore space (Vogel et al., 2010). When the Euler

170 number is positive, the pore network is classified as unconnected, whereas it is connected

171 when the Euler number is negative. The volume of air-filled macropores and Euler number

172 were calculated on the total air-filled pores identified, and the air-filled pores connected to the

173 soil surface only, to evaluate the pore network contributing to $\mathrm{N}_{2} \mathrm{O}$ emissions. We estimated

174 the relative gas diffusion coefficients $D_{\mathrm{S}} / D_{0}$ from the segmented air-filled pore space with 
175 QuantIm v.4 (Vogel, 2008), as already done by Deurer et al. (2009) and Vogel et al. (2002).

176 The gas diffusion was modeled by using the Fick's law of diffusion in 3-D, solved by explicit

177 finite differences. Throughout the simulation, the gas concentration at the bottom of the soil

178 sample was fixed at a constant value, and the gas concentration at the top was set to zero. We

179 calculated $D_{\mathrm{S}} / D_{0}$ on subsamples of increasing thickness from the soil surface (adding 10

180 pixels at the bottom of the given subsample).

\section{Results}

\section{$182 \quad 3.1$ Soil water content and soil water potential evolution}

183 During the drying phase, the WFPS measured with the MSO system ranged between $85 \%$ and $18479 \%$ at $\mathrm{C} 1$, and between $83 \%$ and $79 \%$ at $\mathrm{C} 2$. The soil matric potential was above $0 \mathrm{~cm}$ for 185 the two wetting cycles for the $-4 \mathrm{~cm}$ depth tensiometer, whereas it was slightly under $0 \mathrm{~cm}$ for 186 the $-2 \mathrm{~cm}$ depth tensiometer at C2 (Fig. 3). Saturation was thus slightly lower during C2. The 187 matric potential showed a plateau at the $\mathrm{C} 2$ wetting phase, reached in approximately $4.5 \mathrm{~h}$ 188 after the beginning of the C2 wetting phase. During the drying phase, the matric potential 189 decreased linearly, immediately after activating the vacuum pump, to reach $-56 \mathrm{~cm}$ water 190 column at $\mathrm{C} 1$ and $-67 \mathrm{~cm}$ water column at $\mathrm{C} 2$. The decrease of the matric potential was 191 slightly faster at $\mathrm{C} 2$ than at $\mathrm{C} 1$ (mean decrease of $-8.8 \mathrm{~cm} \mathrm{~h}^{-1}$ at $\mathrm{C} 1$, and $-9.5 \mathrm{~cm} \mathrm{~h}^{-1}$ at $\mathrm{C} 2$ ).

\section{$192 \quad 3.2$ Dynamics of the $\mathrm{N}_{2} \mathrm{O}$ and $\mathrm{CO}_{2}$ fluxes}

193 Emissions were lower during C2 than during C1, both for the wetting and the drying phases,

194 with the maximum $\mathrm{N}_{2} \mathrm{O}$ flux being $55.1 \mathrm{mg} \mathrm{N} \mathrm{m}^{-2} \mathrm{~d}^{-1}$ at $\mathrm{C} 1$, and $19.1 \mathrm{mg} \mathrm{N} \mathrm{m}^{-2} \mathrm{~d}^{-1}$ at $\mathrm{C} 2$ 195 (Fig. 3). Nitrous oxide fluxes were measured to be 9.4 and $0.1 \mathrm{mg} \mathrm{N} \mathrm{m}^{-2} \mathrm{~d}^{-1}$ at the end of the

$196 \mathrm{C} 1$ and C2 wetting phase, respectively. In comparison, they ranged between 0 and $2.6 \mathrm{mg} \mathrm{N}$ $197 \mathrm{~m}^{-2} \mathrm{~d}^{-1}$ in the field measurements of $\mathrm{Gu}$ et al. (2011) on the same study site. Nitrous oxide 
198 fluxes increased quickly during the drying phase to reach a peak approximately $5.5 \mathrm{~h}$ after the

199 beginning of the soil drying at $\mathrm{C} 1$, and $4.5 \mathrm{~h}$ at $\mathrm{C} 2$. Peaks occurred at a mean matric potential 200 of $-41.1 \mathrm{~cm}$ water column at $\mathrm{C} 1$, and $-44.7 \mathrm{~cm}$ at $\mathrm{C} 2$, and at a WFPS of $80.2 \%$ at $\mathrm{C} 1$ and $20180.5 \%$ at $\mathrm{C} 2$. The increase in the $\mathrm{N}_{2} \mathrm{O}$ fluxes was faster for $\mathrm{C} 1$ than for $\mathrm{C} 2$. The first flux 202 measurement of $\mathrm{C} 1$ was especially high (38.2 $\mathrm{mg} \mathrm{N} \mathrm{m}^{-2} \mathrm{~d}^{-1}$ ) compared to the following 203 measurements. At C2, the fluxes measured at the beginning of the drying phase increased 204 more slowly, with fluxes between 3.3 and $3.9 \mathrm{mg} \mathrm{N} \mathrm{m}^{-2} \mathrm{~d}^{-1}$ for the three first measurements.

205 Carbon dioxide fluxes were higher at $\mathrm{C} 2$ than at $\mathrm{C} 1$ at the end of the wetting phase (50.4 mg $206 \mathrm{CO}_{2} \mathrm{~m}^{-2} \mathrm{~d}^{-1}$ at $\mathrm{C} 1$, and $164.1 \mathrm{mg} \mathrm{CO}_{2} \mathrm{~m}^{-2} \mathrm{~d}^{-1}$ at $\mathrm{C} 2$ ). An opposite trend was observed during 207 the drying phase: $\mathrm{CO}_{2}$ fluxes were higher at $\mathrm{C} 1$ than at $\mathrm{C} 2\left(108.3 \mathrm{mg} \mathrm{CO}_{2} \mathrm{~m}^{-2} \mathrm{~d}^{-1}\right.$ at $\mathrm{C} 1$, and $20876.1 \mathrm{mg} \mathrm{CO}_{2} \mathrm{~m}^{-2} \mathrm{~d}^{-1}$ at $\mathrm{C} 2$ ). Soil $\mathrm{pH}$ at the end of the two wetting-drying cycles was 5.9.

\subsection{Characterization of the pore network}

210 Four components could be identified, both visually and in the histograms of each image: air 211 phase, water phase, soil matrix, and gravels (Fig. 4 and 5). We define the soil matrix as the 212 solid phase and pores with a size lower than the image resolution. Histograms appeared to be 213 unimodal, with the mode corresponding to the soil matrix, because the air-filled and water214 filled porosities represented only a small fraction of the soil sample volume (Fig. 4a and 4b). 215 A small peak near the pure air intensity value (-1024 HU) could be identified for the drying 216 phase, and a small peak near the pure water intensity value ( $0 \mathrm{HU})$ could be identified for the 217 wetting phase (Fig. 4c and 4d). Less water voxels and more air voxels were identified at C2 218 than at $\mathrm{C} 1$ during the wetting phase, showing that the water saturation was lower at C2 (Fig. $2194 \mathrm{c}$ and $4 \mathrm{~d})$.

220 A 3-D rendering of the air phase and water phase distributions at the end of the wetting phase 221 and at the end of the drying phase for $\mathrm{C} 1$ and $\mathrm{C} 2$ is given in Fig. 5. Cylindrical pores, 
222 probably earthworm burrows and root channels (of which one major root channel of 223 approximately $9 \mathrm{~mm}$ diameter), as well as smaller pores attributed to inter-aggregate voids are 224 visible. As expected, air-filled pores appeared to be more numerous at the end of the drying 225 phase than at the end of the wetting phase. A high volume of pore remained not saturated 226 during the experiment.

227 Most of the indicators calculated from the segmented images were highly correlated, except 228 the Euler number and $D_{\mathrm{S}} / D_{0}$ (Table 1). Indeed, largest pores highly contributed to the 229 porosity, but relatively little to Euler number (Vogel et al., 2002), and $D_{\mathrm{S}} / D_{0}$ includes 230 additional information about the tortuosity. The air-filled porosity identified ranged between 2310.029 and $0.035 \mathrm{~cm}^{3} \mathrm{~cm}^{-3}$ at $\mathrm{C} 1$, and between 0.023 and $0.035 \mathrm{~cm}^{3} \mathrm{~cm}^{-3}$ at $\mathrm{C} 2$. In the driest 232 scan of $\mathrm{C} 2$, where the maximum air-filled pore volume has been identified, this air-filled 233 porosity is equivalent to $16 \%$ of the real air-filled porosity at a pressure of $-100 \mathrm{hPa}$, or $7.5 \%$ 234 of the total porosity $\left(0.46 \mathrm{~cm}^{3} \mathrm{~cm}^{-3}\right)$. For the total core volume, time-evolution of the air235 filled pore volume showed a rapid rise from the beginning to $1 \mathrm{~h}$ after the soil drying, and 236 then the system entered a state of equilibrium (Fig. 6a). C1 and C2 followed the same trend, 237 but the air-filled pore volume was significantly higher at $\mathrm{C} 2$ than at $\mathrm{C} 1$ at the end of the 238 wetting phase, and slightly higher at $\mathrm{C} 2$ than at $\mathrm{C} 1$ during the drying phase. The volume of 239 water-filled pores decreased quickly in the first hour of soil drying, and remained lower at C2 240 than at $\mathrm{C} 1$ during the whole experiment (Fig. 6a). The evolution of the air-filled pores 241 connected to the soil surface showed the same trend as for the total core volume, except that 242 no more difference can be seen between $\mathrm{C} 1$ and $\mathrm{C} 2$ after $2 \mathrm{~h}$ of soil drying (Fig. 6c).

243 For the total air-filled pore volume identified, the Euler number ranged between 1319 and 2441849 at C1, and between 1405 and 1713 at C2 (Fig. 6b). Thus, the Euler number was positive 245 during the whole experiment, meaning that the air-filled pore network was unconnected at the 246 resolution of the images. The Euler number was lower at $\mathrm{C} 2$ than at $\mathrm{C} 1$ during the wetting 
247 phase, and higher at $\mathrm{C} 2$ than at $\mathrm{C} 1$ during the drying phase. The air-filled pore connectivity 248 was thus better at $\mathrm{C} 1$ during the drying phase. The value of the Euler number tended to 249 decrease with soil drying. For the air-filled pores connected to the soil surface only, the Euler 250 number ranged between -52.5 and 17 at $\mathrm{C} 1$, and between -57 and 1 at $\mathrm{C} 2$ (Fig. 6d). A 251 transition between an unconnected and a connected pore network occurred in the first hour of 252 soil drying: the Euler number was positive at the end of the wetting phase, and negative 253 during the drying phase. The inherent connectivity improved then as the soil dried. The Euler 254 number was higher at $\mathrm{C} 1$ than at $\mathrm{C} 2$ during the whole experiment. One major pore cluster, 255 representing $98 \%$ of the air-filled pore volume connected to the soil surface at the end of the 256 two drying phases, was responsible for the negative value of the Euler number. The other 257 pores were smaller and had a less complicated morphology.

258 Simulated relative gas diffusion coefficients were null for subsamples thicker than 259 approximately $3 \mathrm{~cm}$ at $\mathrm{C} 1$, and $4 \mathrm{~cm}$ at $\mathrm{C} 2$, because deepest pores were poorly connected to 260 the soil surface. Thus, only the upper part of the soil sample could participate to the fast $\mathrm{N}_{2} \mathrm{O}$ 261 transport to the soil surface in the gaseous phase. The evolution with time of the gas diffusion 262 coefficient of a 3-cm-thick subsample is given in Fig. 7. Absolute values of $D_{\mathrm{S}} / D_{0}$ ranged 263 between 0.000 and 0.009 at $\mathrm{C} 1$, and between 0.003 and 0.005 at $\mathrm{C} 2$. They were higher at $\mathrm{C} 2$ 264 than at $\mathrm{C} 1$, except for the first measurement of the $\mathrm{C} 1$ drying phase. Relative gas diffusion 265 coefficients increased quickly after the beginning of the soil drying at $\mathrm{C} 1$, and then showed 266 lower values. This peak at $\mathrm{C} 1$ was concomitant with a fast increase of the $\mathrm{N}_{2} \mathrm{O}$ flux. The 267 increase with soil drying was slower at C2 than at C1. Trends were similar for the estimation 268 of $D_{\mathrm{S}} / D_{0}$ on thinner subsamples (data not shown). 


\section{Discussion}

270

271

272

273

274

275

276

277

278

279

280

281

282

283

284

285

286

287

288

\subsection{The use of X-ray computed tomography for greenhouse gas emission studies}

The experiment of the present study appeared as the first report of coupling between soil imaging, greenhouse gas flux measurements, and hydric control measured on the same sample. The use of X-ray computed tomography allowed identifying spatially the water and gas phases in the macropores, and thus determining the air-filled pore volume of these macropores at successive moments during the soil drying. At the scanner resolution, only $16 \%$ of the real air-filled porosity was identified, and the rest remained unresolved. Indeed, we used a large sample, with a size typical of that used to determine soil hydraulic properties, to approach the representative elementary volume of the soil. The pixel size was thus coarse, approximately $300 \mu \mathrm{m}$. With such a resolution, only macropores are unequivocally recognized, i.e., pores $>300 \mu \mathrm{m}$ with the nomenclature of Jarvis (2007). According to YoungLaplace law (assuming $0^{\circ}$ degree contact angle, interfacial tension for air-water and spherical interfaces), these macropores are expected to drain at a water potential of $-10 \mathrm{~cm}$.

Identifying a higher range of pore sizes would have been informative since macropores participate to $\mathrm{N}_{2} \mathrm{O}$ transport, whereas $\mathrm{N}_{2} \mathrm{O}$ production rather occurs in fine pores of the matrix domain (Heincke and Kaupenjohann, 1999). However, such a coarse resolution has successfully been used in previous studies to link soil structure and gas diffusion. By using Xray computed tomography at a resolution of approximately $500 \mu \mathrm{m}$, Katuwal et al. (2014) observed a high positive correlation between air permeability and the air-filled macroporosity identified in their images. Deurer et al. (2009) explained a major part of the variability of the gas diffusion coefficients by the air-filled porosity and connectivity of pores $>300 \mu \mathrm{m}$ identified with imaging. In the present study, despite the significant fraction of the unresolved pores which were air-filled at the end of the two drying cycles, coarse-resolution X-ray computed tomography can be used to infer $\mathrm{N}_{2} \mathrm{O}$ transport functioning. We also succeeded in 
294 identifying differences in the soil moisture between the two wetting-drying cycles. This 295 difference was consistent with the other parameters recorded, i.e., matric potential and WFPS, 296 and allowed inferring differences in anoxia level in the soil profile between $\mathrm{C} 1$ and $\mathrm{C} 2$. 297 Relative, instead of absolute, comparisons between the two wetting-drying cycles could thus 298 be performed.

\subsection{Nitrous oxide emissions and pore connectivity}

300 After 3 days of water saturation, soil drying down to $-45 \mathrm{~cm}$ water column induced maximum $301 \mathrm{~N}_{2} \mathrm{O}$ fluxes. This result has been previously observed by Rabot et al. (2014). They 302 hypothesized that the gas diffusion coefficient increased as the soil dried and allowed the 303 release of the $\mathrm{N}_{2} \mathrm{O}$ previously entrapped during the wetting phase in the pore space or in the 304 soil solution. Nitrous oxide entrapment in soils at high WFPS has already been highlighted in 305 laboratory experiments (Clough et al., 1998; McCarty et al., 1999; Weier et al., 1993). In this 306 new study, supplementary information about the soil structure was obtained and we were able 307 to measure an increase of the air-filled macropores connected to the soil surface as the soil 308 dried. The air-filled pore network connected to the soil surface was described as well 309 interconnected during the drying phase. Fast $\mathrm{N}_{2} \mathrm{O}$ transport in the gaseous phase could occur 310 from the soil upper part connected to the atmosphere during the drying phase, where some 311 biological hotspots could be active (Ball et al., 2008; van der Weerden et al., 2012). The 312 porous network was probably also connected by pores of a size lower than the one recorded 313 by the X-ray scanner, which represent approximately $85 \%$ of the air-filled pore space at a 314 pressure of $-100 \mathrm{hPa}$. The observed increase of the air-filled pore volume connected to the 315 soil surface, pore connectivity, and relative coefficient of gas diffusion with soil drying favors 316 the hypothesis of Rabot et al. (2014), stating that entrapped $\mathrm{N}_{2} \mathrm{O}$ was released during the 317 drying phase. 
318 By considering the whole pore volume, the pore network was classified as unconnected

319 during the experiment. Firstly, given that the value of the Euler number depends on the size of

320 the lower pore which can be resolved (Vogel et al., 2010), the soil sample may have been

321 connected by unresolved air-filled pores. With a coarse-resolution scanner, we underestimate

322 the connectivity of the soil sample. Secondly, the Euler number is a metrics highly affected by

323 isolated voxels (Renard and Allard, 2013), like unconnected structural pores or thresholding

324 artifacts, leading to highly positive values. Katuwal et al. (2014) observed that the Euler

325 number was not a good measure of macropore connectivity to compare soil samples.

326 Evolution of the Euler number for the whole identified pore volume is thus difficult to

327 interpret, especially as a large fraction of the pore space remained unresolved. We favor the

328 use of the Euler number for the pores connected to the soil surface, which, by construction,

329 includes less isolated pores. Despite a high computational cost, the estimation of $D_{\mathrm{S}} / D_{0}$ from

330 the segmented pore network appeared to better describe $\mathrm{N}_{2} \mathrm{O}$ transport, by showing an

331 evolution similar to that of $\mathrm{N}_{2} \mathrm{O}$ fluxes: a fast increase at $\mathrm{C} 1$ and a slow increase at $\mathrm{C} 2$. The

332 relative gas diffusion coefficient provided comprehensive information, by taking into account

333 the pore network connectivity and tortuosity, and was less affected by isolated voxels.

\section{$334 \quad 4.3 \quad$ Intensity of nitrous oxide emissions}

335 By comparing the two wetting and drying cycles, differences in the amount of $\mathrm{N}_{2} \mathrm{O}$ emitted were observed. Emissions were lower at $\mathrm{C} 2$ than at $\mathrm{C} 1$ both during the wetting and the drying

337 phases. A lower water content at $\mathrm{C} 2$ may have been responsible for the lower $\mathrm{N}_{2} \mathrm{O}$ production

338 during the $\mathrm{C} 2$ wetting phase. Moreover, the higher connectivity and relative gas diffusion

339 coefficient at $\mathrm{C} 2$ during the wetting phase caused lower $\mathrm{N}_{2} \mathrm{O}$ entrapment in soil, and could

340 also explain the lower $\mathrm{N}_{2} \mathrm{O}$ release during the $\mathrm{C} 2$ drying phase. Balaine et al. (2013)

341 suggested that $\mathrm{N}_{2} \mathrm{O}$ emissions were low for $D_{\mathrm{S}} / D_{0}<0.006$ in their experiment on repacked

342 soil samples at a hydric steady-state, because $\mathrm{N}_{2} \mathrm{O}$ was entrapped in the soil and because the 
343 reduction of $\mathrm{N}_{2} \mathrm{O}$ into $\mathrm{N}_{2}$ was high. The observations in our present study support these

344 findings, as we estimated values of $D_{\mathrm{S}} / D_{0}<0.006$ during the wetting phase, and we observed

$345 \mathrm{~N}_{2} \mathrm{O}$ entrapment. Nitrous oxide reduction into $\mathrm{N}_{2}$ is expected to occur two or three days after

346 the water saturation of a soil sample (Letey et al., 1980). Nitrous oxide consumption probably

347 occurred in the present study during the wetting phase, as WFPS $>90 \%$ favors this reaction

348 (Ruser et al., 2006). Small differences in WFPS between the wetting phases of C1 and C2

349 could have caused differences in $\mathrm{N}_{2} \mathrm{O}$ consumption. In the literature, reduced $\mathrm{N}_{2} \mathrm{O}$ production

350 after a second wetting and drying cycle has also been explained by the $\mathrm{C}$ and $\mathrm{N}$ dynamics in

351 relation to the microbial dynamics activity (Fierer and Schimel, 2002; Mikha et al., 2005;

352 Muhr et al., 2008). In our study, nitrate was supplied in excess during the wetting phase of

353 each wetting-drying cycle, so nitrate was supposed not to be limiting at the beginning of each

354 wetting-drying phase. On the contrary, the carbon dynamics can be implicated in the lower

355 emissions at $\mathrm{C} 2$. A shortage of $\mathrm{C}$ after a first wetting-drying cycle may have consumed easily

356 available C substrates (Fierer and Schimel, 2002), and/or less C substrates may have been

357 exposed to microbial consumption at $\mathrm{C} 2$, by the physical disruption of soil aggregates during

358 the wetting-drying cycles (Denef et al., 2001).

\section{$359 \quad 4.4 \quad$ Timing of nitrous oxide emissions}

360 In addition to the differences in terms of intensities of $\mathrm{N}_{2} \mathrm{O}$ emissions between the two wetting

361 and drying cycles, differences in the timing of the $\mathrm{N}_{2} \mathrm{O}$ peaks were also observed. The matric

362 potential appeared to be a good indicator of the timing of $\mathrm{N}_{2} \mathrm{O}$ emissions, as already shown by

363 Castellano et al. (2010), because the matric potential defines the diameter of the water-filled

364 pores. We found that maximum $\mathrm{N}_{2} \mathrm{O}$ fluxes were reached at approximately $-45 \mathrm{~cm}$ water

365 column, that is to say when pores with diameter $>66 \mu \mathrm{m}$ were drained. This is consistent with

366 the experiment of Castellano et al. (2010), who observed in their free drainage experiment

367 that $\mathrm{N}_{2} \mathrm{O}$ peaks occurred when pores with diameter $>80 \mu \mathrm{m}$ were drained. In the experiment 
368 of Balaine et al. (2013), $\mathrm{N}_{2} \mathrm{O}$ peaks were observed when pores with diameter $>197$ and $>57$

$369 \mu \mathrm{m}$ were drained, in soils repacked at bulk densities 1.1 and $1.5 \mathrm{~g} \mathrm{~cm}^{-3}$, respectively.

370 The timing can also be compared between the two wetting-drying cycles. In our study, $\mathrm{N}_{2} \mathrm{O}$

371 fluxes were very high soon after the beginning of the $\mathrm{C} 1$ drying phase contrary to $\mathrm{C} 2$. Indeed,

372 less $\mathrm{N}_{2} \mathrm{O}$ may have been produced during the $\mathrm{C} 2$ wetting phase, leading to a lower gas

373 concentration gradient between the soil surface and the atmosphere, and thus to a slower gas

374 diffusion. Moreover, the lower rate of increase at $\mathrm{C} 2$ than at $\mathrm{C} 1$ of the air-filled pore volume,

375 connectivity, and relative gas diffusion coefficient, at the beginning of the drying phase, could

376 also explain the slower $\mathrm{N}_{2} \mathrm{O}$ emissions at the beginning of the $\mathrm{C} 2$ drying phase. These

377 variables were highly correlated, so only one of them could have been computed. The volume

378 of air-filled pores and the Euler number of pores connected to the soil surface were easily

379 calculated, but the relative gas diffusion coefficient appeared to be more efficient to describe

380 the timing of $\mathrm{N}_{2} \mathrm{O}$ emissions.

\section{Conclusion}

382 We hypothesized that introducing dynamic indicators of the soil structure could enhance our

383 understanding of the dynamic nature of $\mathrm{N}_{2} \mathrm{O}$ emissions by soils. The experiment performed in

384 this study was intended to demonstrate the ability of a coupling between coarse-resolution X-

385 ray computed tomography, hydric control and $\mathrm{N}_{2} \mathrm{O}$ flux measurements, to better describe $\mathrm{N}_{2} \mathrm{O}$

386 transport in soils. X-ray computed tomography is a rapid and non-destructive method, which

387 allowed measuring an evolution of the air phase volume, pore connectivity, and estimating the

388 relative gas diffusion coefficient during successive wetting-drying cycles on the same soil

389 sample. Contrary to the use of other characterization techniques (e.g., measurements of the

390 gas diffusion coefficient with the one-chamber method), the hydric status of the soil has not 
391 been modified by supplementary wetting-drying cycles, and $\mathrm{N}_{2} \mathrm{O}$ entrapment has not been 392 disrupted.

393 We were able to measure an increase of the volume of the air phase connected to the soil 394 surface, and an increase of the pore connectivity and gas diffusion coefficient as the soil dried. 395 We used the Euler number as an indicator of the connectivity of the gas phase. Because this 396 metrics is highly affected by isolated pores, we based our interpretations on the Euler number 397 calculated for the pore space connected to the soil surface, rather than for the whole pore 398 space identified with imaging. Nitrous oxide emissions were lower in terms of intensity and 399 speed during the second drying cycle. Differences in the intensity of $\mathrm{N}_{2} \mathrm{O}$ emissions were 400 attributed to differences in the water saturation, air-phase connectivity, and relative gas 401 diffusion coefficient, which led to more or less $\mathrm{N}_{2} \mathrm{O}$ production, consumption, and entrapment 402 in soil. The speed of the $\mathrm{N}_{2} \mathrm{O}$ release at the beginning of the drying phase depended on the 403 rate of increase of the air-filled pore volume, connectivity, and was especially well described 404 by the relative gas diffusion coefficient. Parameters of the soil structure were not able to 405 explain completely the intensity of $\mathrm{N}_{2} \mathrm{O}$ emissions during drying, as $\mathrm{N}_{2} \mathrm{O}$ production and 406 consumption factors modified the $\mathrm{N}_{2} \mathrm{O}$ concentration gradient between the soil and the 407 atmosphere.

408 The soil structure can be seen as a factor of the $\mathrm{N}_{2} \mathrm{O}$ flux intensity because the pore size 409 controls $\mathrm{N}_{2} \mathrm{O}$ production by providing a favorable microbial habitat (i.e., aerobic status, 410 substrate availability, water potential), and because the pore tortuosity and connectivity to the 411 soil surface controls $\mathrm{N}_{2} \mathrm{O}$ emission. This study highlighted the need to find and measure 412 dynamic indicators of the soil structure, to enhance our understanding of the dynamic nature 413 of $\mathrm{N}_{2} \mathrm{O}$ emissions by soils. The results presented here are an illustration based on one soil 414 sample, but the methodology is widely applicable. Even if imaging with a coarse scanner 
415 resolution provided valuable data, imaging techniques at a finer spatial resolution, able to 416 identify pores with diameter of approximately $50 \mu \mathrm{m}$, would allow refining these results.

\section{Acknowledgements}

418 We are grateful to D. Colosse, P. Courtemanche, and G. Giot for their technical help in the 419 experimental design and/or field sampling. We also thank S. Sammartino (INRA, UMR

420 EMMAH) for help with the image analysis. CT-scan imaging was graciously performed by 421 the CIRE platform (INRA Val de Loire, site de Tours, UMR PRC), and carbon and nitrogen 422 analyses were graciously performed by the SAS Laboratoire. This work was supported by a 423 Conseil Général du Loiret grant, by the Spatioflux program funded by the Région Centre, 424 FEDER, INRA and BRGM, and by the Labex VOLTAIRE (ANR-10-LABX-100-01). 
425

426

427

428

429

430

431

432

433

434

435

436

437

438

439

440

441

442

443

444

445

446

447

448

\section{References}

Balaine, N., T.J. Clough, M.H. Beare, S.M. Thomas, E.D. Meenken, and J.G. Ross. 2013. Changes in relative gas diffusivity explain soil nitrous oxide flux dynamics. Soil Sci. Soc. Am. J. 77:1496-1505.

Ball, B.C. 2013. Soil structure and greenhouse gas emissions: A synthesis of 20 years of experimentation. Eur. J. Soil Sci. 64:357-373.

Ball, B.C., I. Crichton, and G.W. Horgan. 2008. Dynamics of upward and downward $\mathrm{N}_{2} \mathrm{O}$ and $\mathrm{CO}_{2}$ fluxes in ploughed or no-tilled soils in relation to water-filled pore space, compaction and crop presence. Soil Tillage Res. 101:20-30.

Butterbach-Bahl, K., E.M. Baggs, M. Dannenmann, R. Kiese, and S. ZechmeisterBoltenstern. 2013. Nitrous oxide emissions from soils: How well do we understand the processes and their controls? Philos. Trans. R. Soc. B 368.

Castellano, M.J., J.P. Schmidt, J.P. Kaye, C. Walker, C.B. Graham, H. Lin, et al. 2010. Hydrological and biogeochemical controls on the timing and magnitude of nitrous oxide flux across an agricultural landscape. Glob. Change Biol. 16:2711-2720.

Ciais, P., C. Sabine, G. Bala, L. Bopp, V. Brovkin, J. Canadell, et al. 2013. Carbon and other biogeochemical cycles. In: Stocker, T.F., D. Qin, G.K. Plattner, M. Tignor, S.K. Allen, J. Boschung, et al., editors, Climate change 2013: The physical science basis. Contribution of working group I to the fifth assessment report of the intergovernmental panel on climate change. Cambridge University Press, Cambridge, United Kingdom and New York, NY, USA. p. 465-570.

Clough, T.J., S.C. Jarvis, E.R. Dixon, R.J. Stevens, R.J. Laughlin, and D.J. Hatch. 1998. Carbon induced subsoil denitrification of ${ }^{15} \mathrm{~N}$-labelled nitrate in $1 \mathrm{~m}$ deep soil columns. Soil Biol. Biochem. 31:31-41. 
449 Clough, T.J., R.R. Sherlock, and D.E. Rolston. 2005. A review of the movement and fate of $450 \quad \mathrm{~N}_{2} \mathrm{O}$ in the subsoil. Nutr. Cycl. Agroecosyst. 72:3-11.

451 Denef, K., J. Six, H. Bossuyt, S.D. Frey, E.T. Elliott, R. Merckx, et al. 2001. Influence of dry452 wet cycles on the interrelationship between aggregate, particulate organic matter, and 453 microbial community dynamics. Soil Biol. Biochem. 33:1599-1611.

454 Deurer, M., D. Grinev, I. Young, B.E. Clothier, and K. Müller. 2009. The impact of soil 455 carbon management on soil macropore structure: A comparison of two apple orchard $456 \quad$ systems in New Zealand. Eur. J. Soil Sci. 60:945-955.

Doube, M., M.M. Klosowski, I. Arganda-Carreras, F.P. Cordelières, R.P. Dougherty, J.S. Jackson, et al. 2010. BoneJ: Free and extensible bone image analysis in ImageJ. Bone 47:1076-1079.

Fierer, N., and J.P. Schimel. 2002. Effects of drying-rewetting frequency on soil carbon and nitrogen transformations. Soil Biol. Biochem. 34:777-787.

Groffman, P.M., and J.M. Tiedje. 1988. Denitrification hysteresis during wetting and drying cycles in soil. Soil Sci. Soc. Am. J. 52:1626-1629.

Gu, J.X., B. Nicoullaud, P. Rochette, D.J. Pennock, C. Hénault, P. Cellier, et al. 2011. Effect of topography on nitrous oxide emissions from winter wheat fields in Central France. Environ. Pollut. 159:3149-3155.

Guo, X.B., C.F. Drury, X.M. Yang, W.D. Reynolds, and R.Q. Fan. 2014. The extent of soil drying and rewetting affects nitrous oxide emissions, denitrification, and nitrogen mineralization. Soil Sci. Soc. Am. J. 78:194-204.

Heincke, M., and M. Kaupenjohann. 1999. Effects of soil solution on the dynamics of $\mathrm{N}_{2} \mathrm{O}$ emissions: A review. Nutr. Cycl. Agroecosyst. 55:133-157. 
472 Hénault, C., and J.C. Germon. 2000. NEMIS, a predictive model of denitrification on the field 473 scale. Eur. J. Soil Sci. 51:257-270.

474

475

476

477

478

479

480

481

482

483

484

485

486

487

488

489

490

491

492

493

Jarvis, N.J. 2007. A review of non-equilibrium water flow and solute transport in soil macropores: Principles, controlling factors and consequences for water quality. Eur. J. Soil Sci. 58:523-546.

Kasteel, R., H.J. Vogel, and K. Roth. 2000. From local hydraulic properties to effective transport in soil. Eur. J. Soil Sci. 51:81-91.

Katuwal, S., T. Norgaard, P. Moldrup, M. Lamandé, D. Wildenschild, and L.W. de Jonge. 2015. Linking air and water transport in intact soils to macropore characteristics inferred from X-ray computed tomography. Geoderma 237-238:9-20.

Khalil, M.A.K., R.A. Rasmussen, and M.J. Shearer. 2002. Atmospheric nitrous oxide: Patterns of global change during recent decades and centuries. Chemosphere 47:807821.

Letey, J., N. Valoras, A. Hadas, and D.D. Focht. 1980. Effect of air-filled porosity, nitrate concentration, and time on the ratio of $\mathrm{N}_{2} \mathrm{O} / \mathrm{N}_{2}$ evolution during denitrification. $\mathrm{J}$. Environ. Qual. 9:227-231.

Mangalassery, S., S. Sjögersten, D.L. Sparkes, C.J. Sturrock, J. Craigon, and S.J. Mooney. 2014. To what extent can zero tillage lead to a reduction in greenhouse gas emissions from temperate soils? Sci. Rep. 4, 4586.

Mangalassery, S., S. Sjögersten, D.L. Sparkes, C.J. Sturrock, and S.J. Mooney. 2013. The effect of soil aggregate size on pore structure and its consequence on emission of greenhouse gases. Soil Tillage Res. 132:39-46. 
494 McCarty, G.W., D.R. Shelton, and A.M. Sadeghi. 1999. Influence of air porosity on 495 distribution of gases in soil under assay for denitrification. Biol. Fert. Soils 30:173$496 \quad 178$.

497 Mikha, M.M., C.W. Rice, and G.A. Milliken. 2005. Carbon and nitrogen mineralization as 498 affected by drying and wetting cycles. Soil Biol. Biochem. 37:339-347.

499 Muhr, J., S.D. Goldberg, W. Borken, and G. Gebauer. 2008. Repeated drying-rewetting cycles 500 and their effects on the emission of $\mathrm{CO}_{2}, \mathrm{~N}_{2} \mathrm{O}, \mathrm{NO}$, and $\mathrm{CH}_{4}$ in a forest soil. J. Plant $501 \quad$ Nutr. Soil Sci. 171:719-728.

502 Naveed, M., S. Hamamoto, K. Kawamoto, T. Sakaki., M. Takahashi, T. Komatsu, et al. 2013. 503 Correlating gas transport parameters and X-ray computed tomography measurements $504 \quad$ in porous media. Soil Sci. 178:60-68.

505 Parker, $\quad$ J.A. 2012. Stack Alignment $\quad$ (Align3_TP). 506 http://www.med.harvard.edu/jpnm/ij/plugins/Align3TP.html.

507 Rabot, E., C. Hénault, and I. Cousin. 2014. Temporal variability of nitrous oxide emissions by 508 soils as affected by hydric history. Soil Sci. Soc. Am. J. 78:434-444.

509 Rasband, W.S. 1997-2014. ImageJ. U.S. National Institutes of Health, Bethesda, Maryland, $510 \quad$ USA, http://imagej.nih.gov/ij.

511 Ravishankara, A.R., J.S. Daniel, and R.W. Portmann. 2009. Nitrous oxide $\left(\mathrm{N}_{2} \mathrm{O}\right)$ : The 512 dominant ozone-depleting substance emitted in the $21^{\text {st }}$ century. Science $326: 123-125$.

513 Renard, P., and D. Allard. 2013. Connectivity metrics for subsurface flow and transport. Adv. $514 \quad$ Water Resour. 51:168-196. 
515 Ruser, R., H. Flessa, R. Russow, G. Schmidt, F. Buegger, and J.C. Munch. 2006. Emission of $516 \mathrm{~N}_{2} \mathrm{O}, \mathrm{N}_{2}$ and $\mathrm{CO}_{2}$ from soil fertilized with nitrate: Effect of compaction, soil moisture 517 and rewetting. Soil Biol. Biochem. 38:263-274.

518 Robertson, G.P. 1989. Nitrification and denitrification in humid tropical ecosystems: Potential 519 controls on nitrogen retention. In: J. Proctor, editor, Mineral nutrients in tropical forest and savanna ecosystems. Blackwell Science, Oxford, U.K. p. 55-69.

521

Sammartino, S., E. Michel, and Y. Capowiez. 2012. A novel method to visualize and characterize preferential flow in undisturbed soil cores by using multislice helical CT. Vadose Zone J. 11:86-98.

Sanchez-Martin, L., A. Sanz-Cobena, A. Meijide, M. Quemada, and A. Vallejo. 2010. The importance of the fallow period for $\mathrm{N}_{2} \mathrm{O}$ and $\mathrm{CH}_{4}$ fluxes and nitrate leaching in a Mediterranean irrigated agroecosystem. Eur. J. Soil Sci. 61:710-720.

Schjønning, P., M. Lamandé, F.E. Berisso, A. Simojoki, L. Alakukku, and R.R. Andreasen. 2013. Gas diffusion, non-darcy air permeability, and computed tomography images of a clay subsoil affected by compaction. Soil Sci. Soc. Am. J. 77:1977-1990.

Schlüter, S., A. Sheppard, K. Brown, and D. Wildenschild. 2014. Image processing of multiphase images obtained via X-ray microtomography: A review. Water Resour. Res. 50:3615-3639.

Schlüter, S., U. Weller, and H.J. Vogel. 2011. Soil-structure development including seasonal dynamics in a long-term fertilization experiment. J. Plant Nutr. Soil Sci. 174:395-403.

Schmid, B., J. Schindelin, A. Cardona, M. Longair, and M. Heisenberg. 2010. A high-level 3D visualization API for Java and ImageJ. BMC Bioinformatics 11.

Sexstone, A.J., T.B. Parkin, and J.M. Tiedje. 1985. Temporal response of soil denitrification rates to rainfall and irrigation. Soil Sci. Soc. Am. J. 49:99-103. 
539 Smith, K.A. 1980. A model of the extent of anaerobic zones in aggregated soils, and its potential application to estimates of denitrification. J. Soil Sci. 31:263-277.

541

542

543

544

545

546

547

548

549

550

551

552

553

554

555

556

557

558

559

560

van der Weerden, T.J., F.M. Kelliher, and C.A.M. de Klein. 2012. Influence of pore size distribution and soil water content on nitrous oxide emissions. Soil Res. 50:125-135.

Vogel, H.J. 2008. QuantIm: C/C++ library for scientific image processing. Helmholtz Center for Environmental Research, Halle, Germany.

Vogel, H.J, I. Cousin, and K. Roth. 2002. Quantification of pore structure and gas diffusion as function of scale. Eur. J. Soil Sci. 53:465-473.

Vogel, H.J., U. Weller, and S. Schlüter. 2010. Quantification of soil structure based on Minkowski functions. Comput. Geosci. 36:1236-1245.

Weier, K.L., J.W. Doran, J.F. Power, and D.T. Walters. 1993. Denitrification and the dinitrogen/nitrous oxide ratio as affected by soil water, available carbon, and nitrate. Soil Sci. Soc. Am. J. 57:66-72.

Weihermüller, L., J.A. Huisman, A. Graf, M. Herbst, and J.M. Sequaris. 2009. Multistep outflow experiments to determine soil physical and carbon dioxide production parameters. Vadose Zone J. 8:772-782.

Wildenschild, D., J.W. Hopmans, M.L. Rivers, and A.J.R. Kent. 2005. Quantitative analysis of flow processes in a sand using synchrotron-based X-ray microtomography. Vadose Zone J. 4:112-126.

Wollersheim, R., G. Trolldenier, and H. Beringer. 1987. Effect of bulk density and soil water tension on denitrification in the rhizosphere of spring wheat (Triticum vulgare). Biol. Fert. Soils 5:181-187. 
561 World Meteorological Organization. 2007. Scientific assessment of ozone depletion: 2006, 562 global ozone research and monitoring project. Global Ozone Res. Monit. Project Rep.

563 50. World Meteorol. Organ., Geneva 


\section{$564 \quad$ Figure captions}

565 Fig. 1. Schematic overview of the multistep outflow system for hydric control and nitrous

566 oxide measurements. Intensity values corresponding to air and water are zoomed in (c) and

567 (d).

568 Fig. 2. Example of a gray scale slice with the segmented water and air, at the end of the 569 wetting phase and at the end of the drying phase.

570 Fig. 3. Evolution with time of the nitrous oxide fluxes and the matric potential measured by

571 the two tensiometers. Gray areas represent the drying phases, and white areas the wetting

572 phases. $\mathrm{C} 1$ is the first wetting-drying cycle, and $\mathrm{C} 2$ is the second wetting-drying cycle.

573 Fig. 4. Histograms of intensity values (16-bit), for (a) the first wetting-drying cycle, and (b)

574 the second wetting-drying cycle. Intensity values corresponding to air and water are zoomed 575 in (c) and (d).

576 Fig. 5. Three-dimensional distribution of the air phase (grey) and the water phase (blue) at the 577 end of the wetting phase and at the end of the drying phase for the two wetting-drying cycles.

578 Fig. 6. Evolution with time of (a) the air-filled and water-filled pore volume, and (b) the Euler

579 number of the total pore volume, (c) the air-filled pore volume, and (d) the Euler number of

580 the pores connected to the soil surface, for the first and second wetting-drying cycles. The 581 zero reference time is the beginning of the drying phase.

582 Fig. 7. Evolution with time of the relative gas diffusion coefficient of a 3-cm-thick subsample,

583 for the first and second wetting-drying cycles. The zero reference time is the beginning of the 584 drying phase. 


\section{Tables}

586 Table 1. Pearson correlation matrix of the indicators extracted from the segmented X-ray images.

\begin{tabular}{|c|c|c|c|c|c|c|}
\hline Variables & $\begin{array}{l}\text { Euler } \\
\text { number }(\mathrm{T})\end{array}$ & $\begin{array}{l}\text { Euler } \\
\text { number }(\mathrm{S})\end{array}$ & $\begin{array}{l}\text { Air volume } \\
(\mathrm{T})\end{array}$ & $\begin{array}{l}\text { Air volume } \\
(\mathrm{S})\end{array}$ & $\begin{array}{l}\text { Water } \\
\text { volume }(\mathrm{T})\end{array}$ & $\begin{array}{l}\text { Gas diffusion } \\
\text { coefficient }(\mathrm{T})\end{array}$ \\
\hline Euler number $(\mathrm{T})$ & 1.00 & & & & & \\
\hline Euler number (S) & 0.44 & 1.00 & & & & \\
\hline Air volume $(\mathrm{T})$ & -0.67 & -0.91 & 1.00 & & & \\
\hline Air volume (S) & -0.72 & -0.86 & 0.99 & 1.00 & & \\
\hline Water volume $(\mathrm{T})$ & 0.65 & 0.77 & -0.94 & -0.95 & 1.00 & \\
\hline $\begin{array}{l}\text { Gas diffusion } \\
\text { coefficient }(\mathrm{T})\end{array}$ & 0.01 & -0.12 & 0.23 & 0.24 & -0.41 & 1.00 \\
\hline
\end{tabular}

$\mathrm{T}$, calculated on the total air-filled pores identified; $\mathrm{S}$, calculated on the air-filled pores connected to the soil surface. 


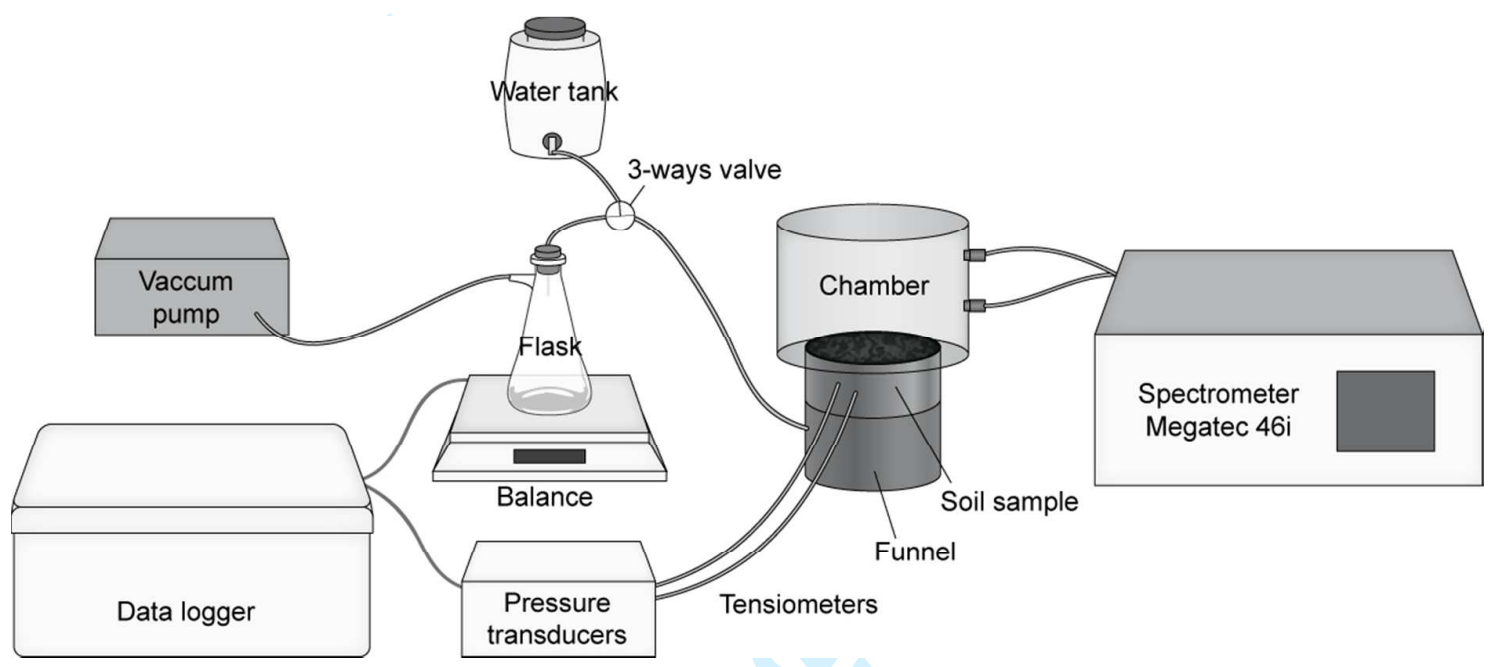

Fig. 1. Schematic overview of the multistep outflow system for hydric control and nitrous oxide measurements. 


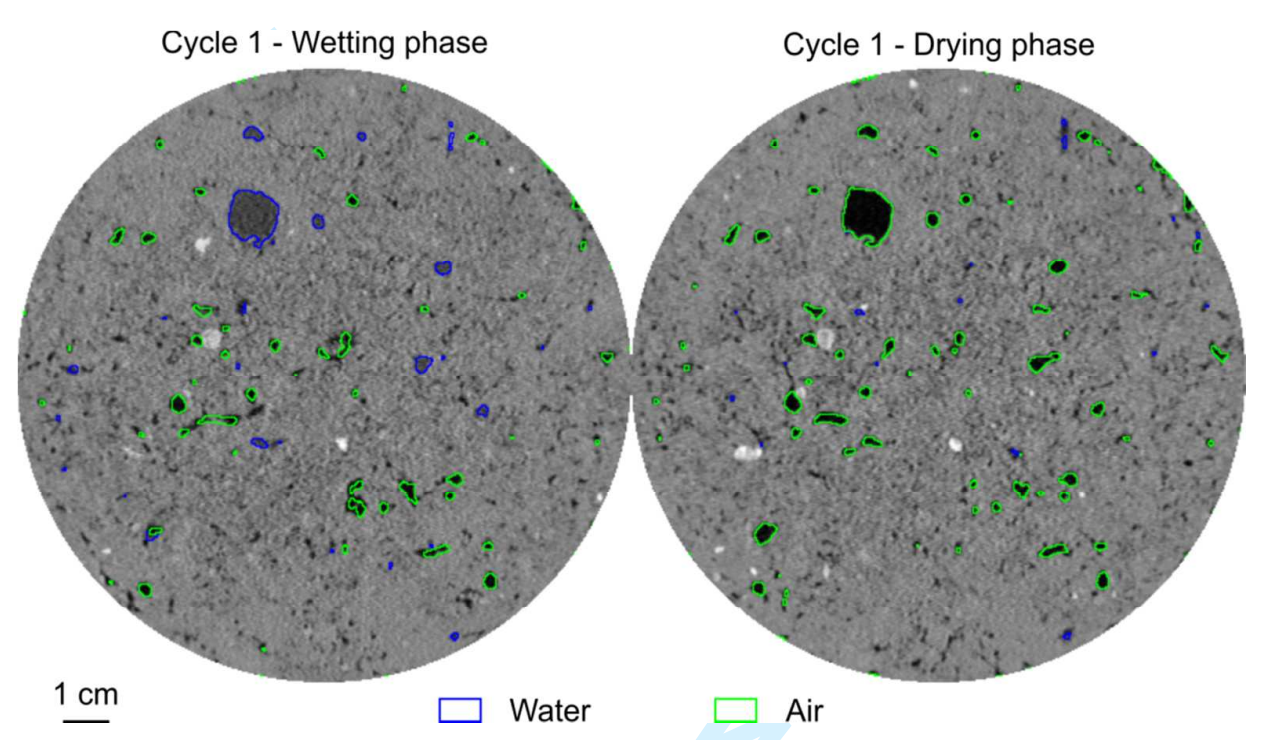

Fig. 2. Example of a gray scale slice with the segmented water and air, at the end of the wetting phase and at the end of the drying phase. 


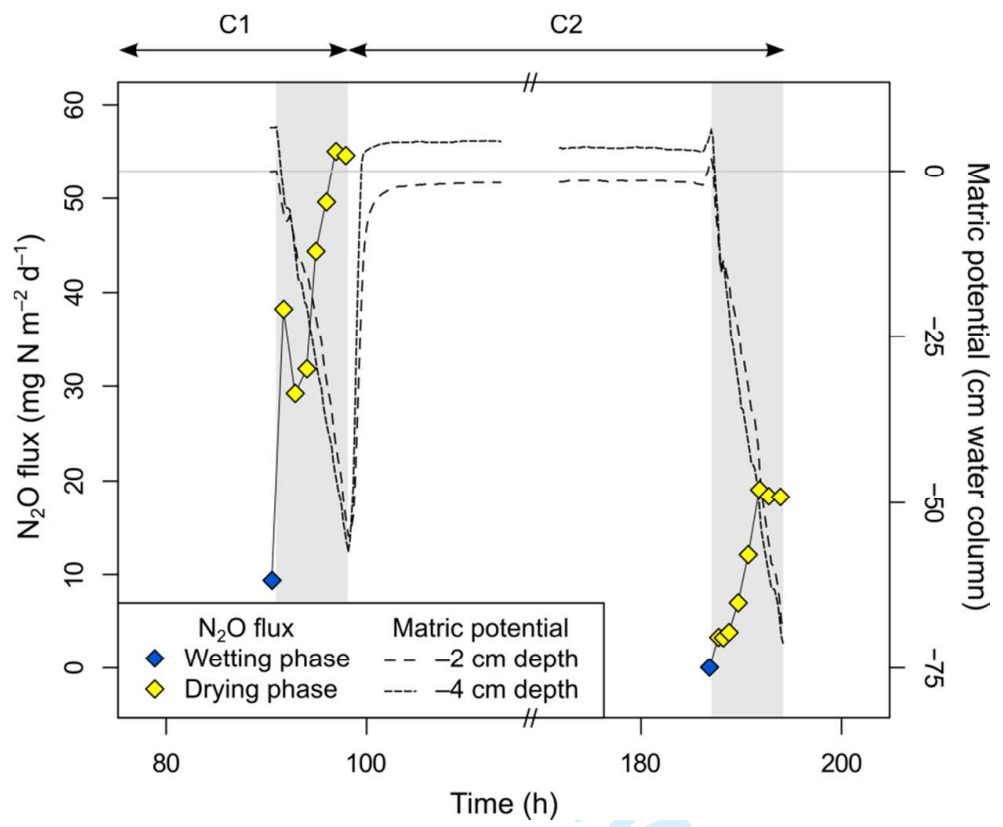

Fig. 3. Evolution with time of the nitrous oxide fluxes and the matric potential measured by the two tensiometers. Gray areas represent the drying phases, and white areas the wetting phases. $\mathrm{C1}$ is the first wetting-drying cycle, and $\mathrm{C} 2$ is the second wetting-drying cycle. 

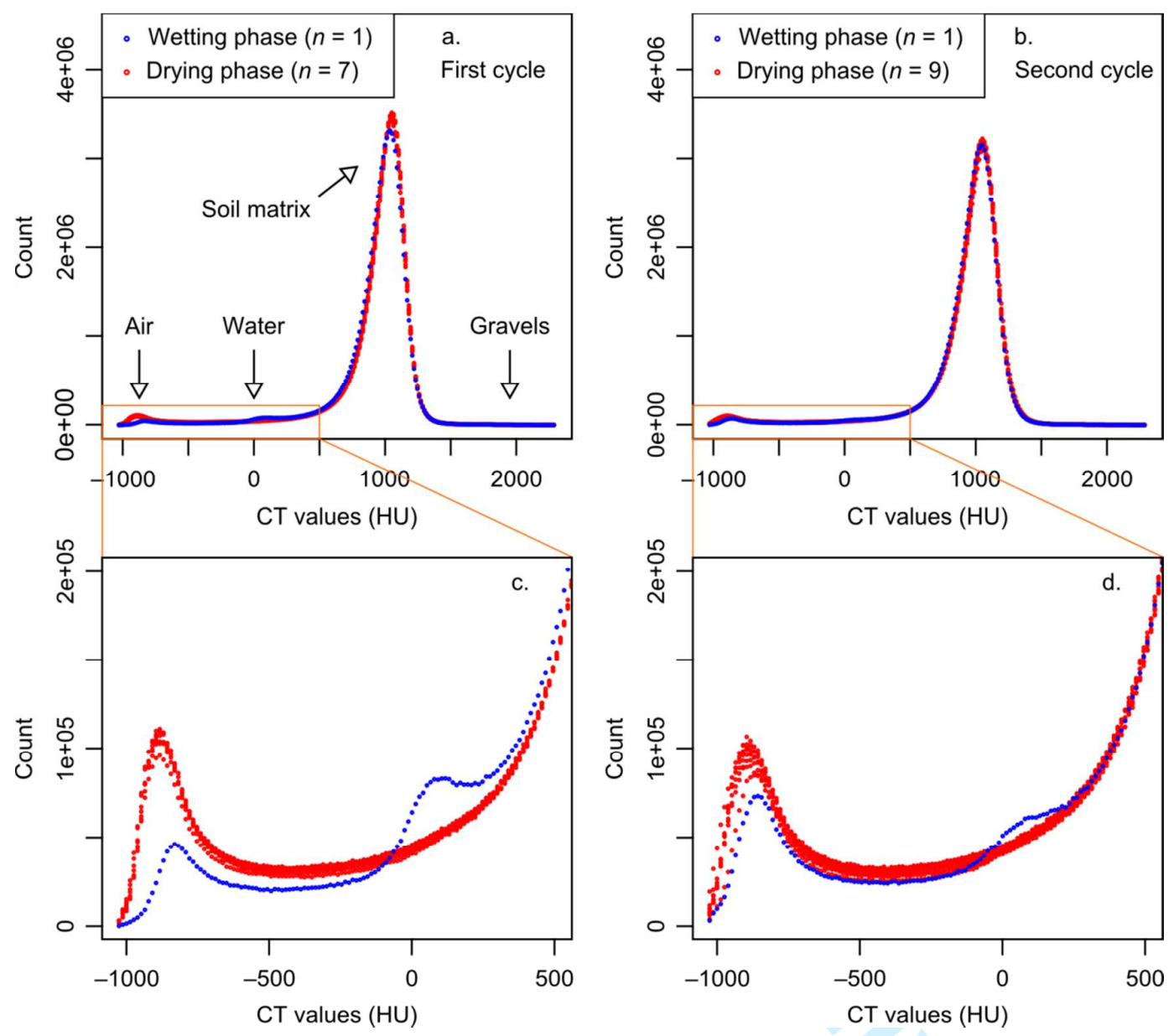

Fig. 4. Histograms of intensity values (16-bit), for (a) the first wetting-drying cycle, and (b) the second wetting-drying cycle. Intensity values corresponding to air and water are zoomed in (c) and (d). 

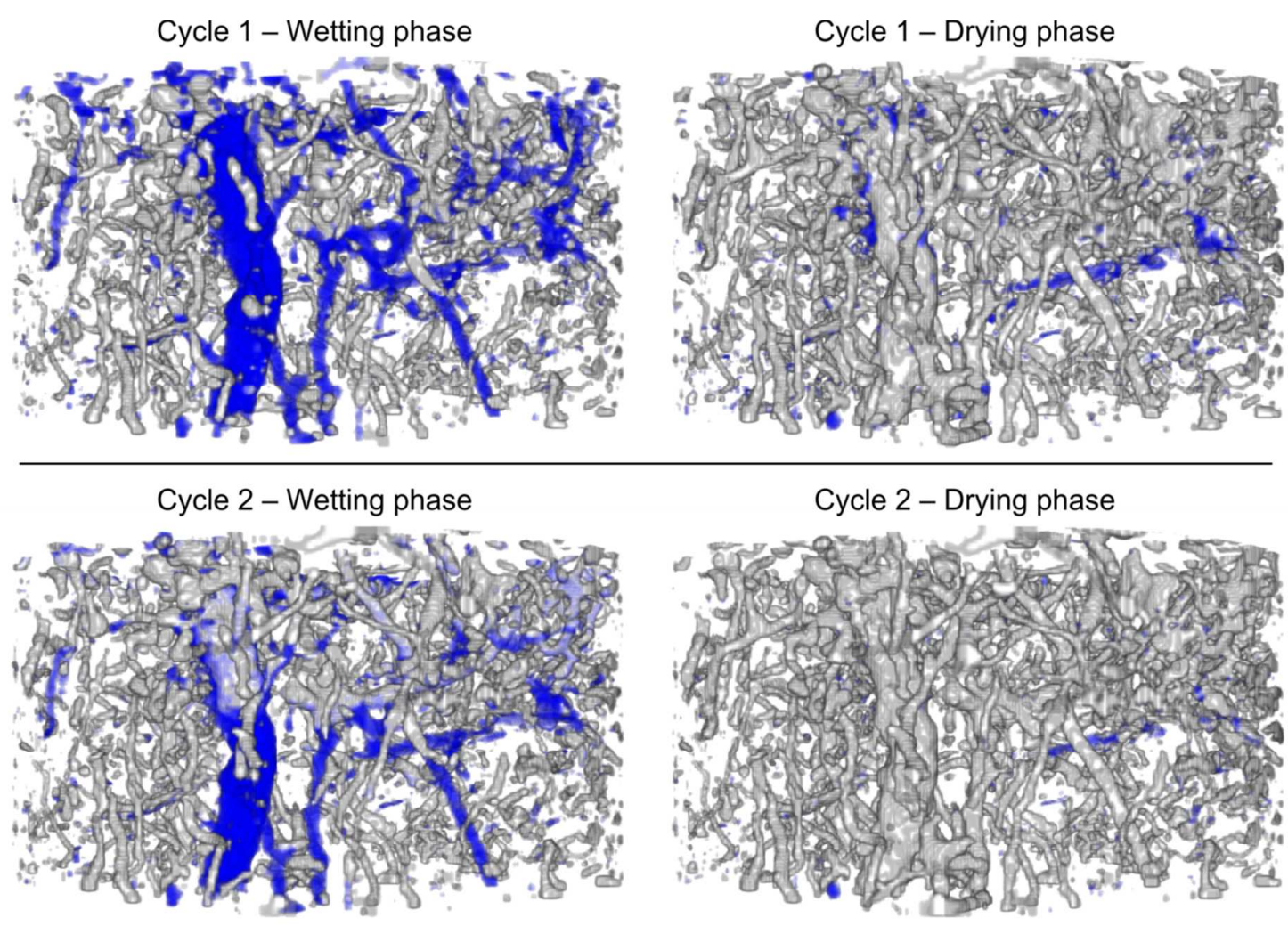

Fig. 5. Three-dimensional distribution of the air phase (grey) and the water phase (blue) at the end of the wetting phase and at the end of the drying phase for the two wetting-drying cycles. 

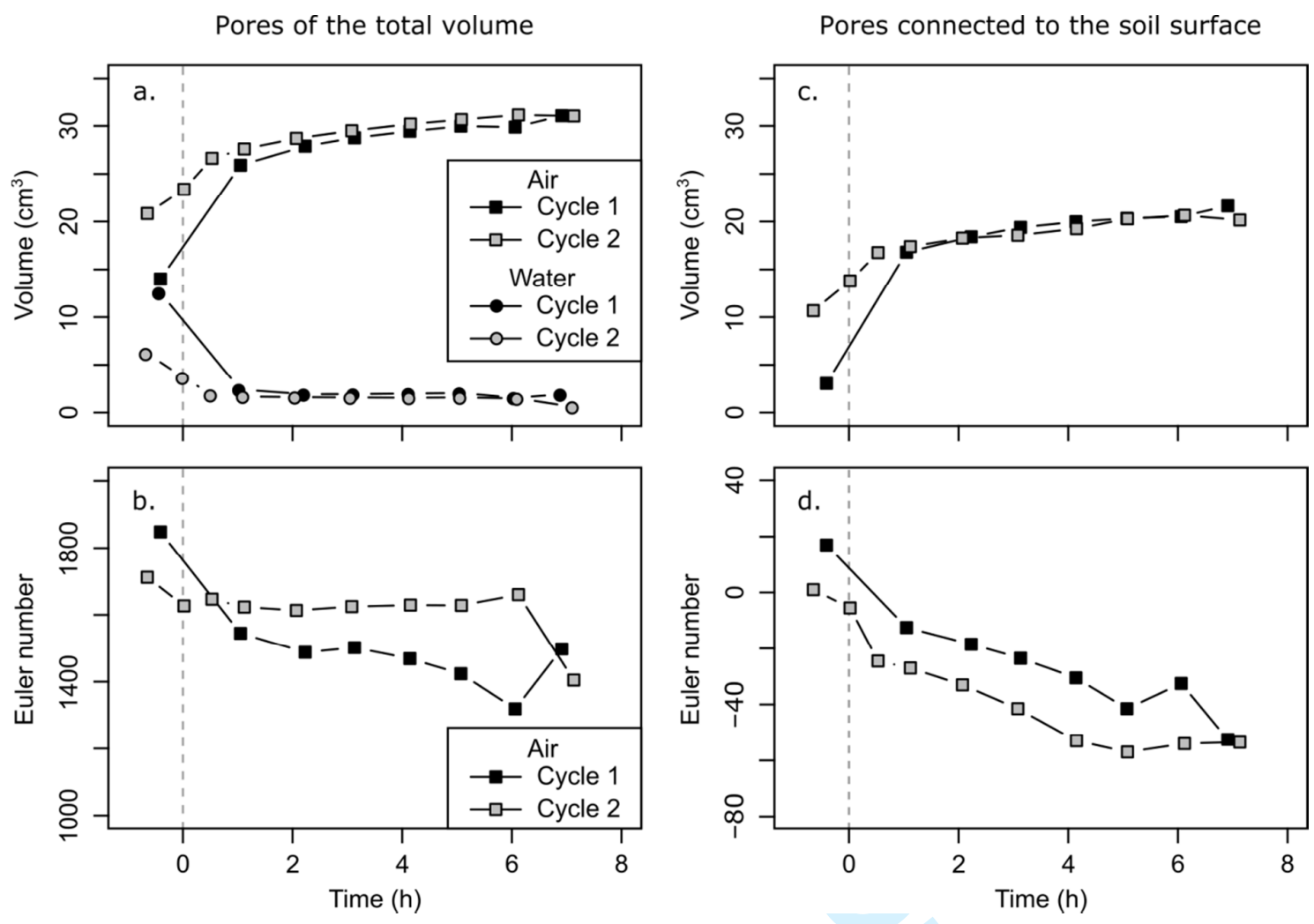

Fig. 6. Evolution with time of (a) the air-filled and water-filled pore volume, and (b) the Euler number of the total pore volume, (c) the air-filled pore volume, and (d) the Euler number of the pores connected to the soil surface, for the first and second wetting-drying cycles. The zero reference time is the beginning of the drying phase. 


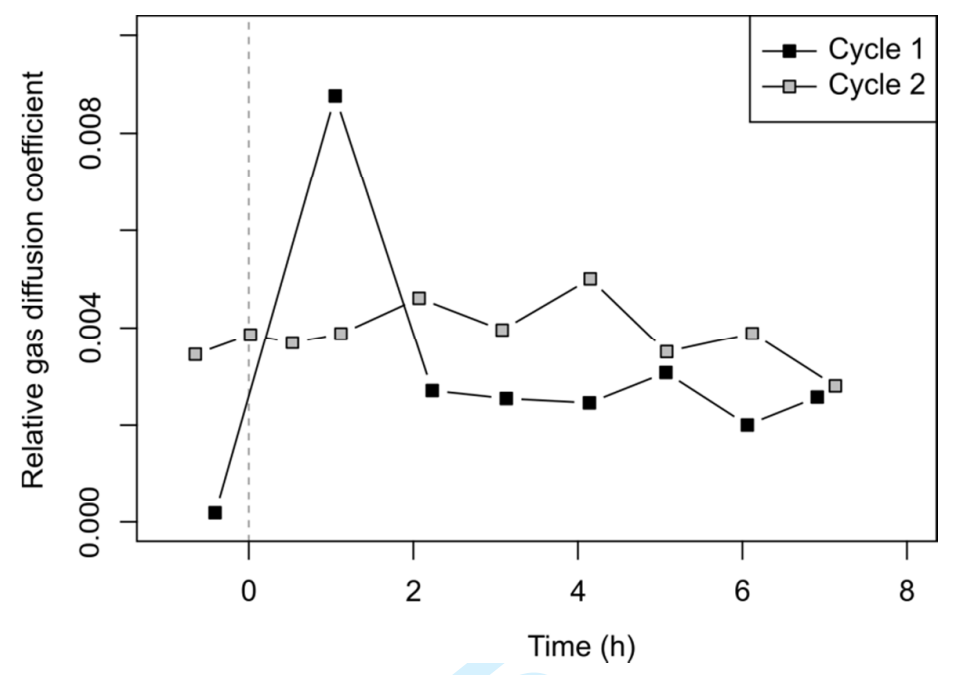

Fig. 7. Evolution with time of the relative gas diffusion coefficient of a 3-cm-thick subsample, for the first and second wetting-drying cycles. The zero reference time is the beginning of the drying phase. 